\title{
When the Personal and the Collective Merge into Oneness: The Dynamics of Memory in Petina Gappah's The Book of Memory
}

\author{
Mamadou Abdou Babou Ngom \\ English Department, Faculty of the Humanities, Cheikh Anta Diop University, Dakar, Senegal \\ Email: mamadou35.ngom@ucad.edu.sn, lamzosaf@gmail.com
}

How to cite this paper: Ngom, M. A. B. (2022). When the Personal and the Collective Merge into Oneness: The Dynamics of Memory in Petina Gappah's The Book of Memory. Advances in Literary Study, 10, 3865.

https://doi.org/10.4236/als.2022.101003

Received: October 9, 2021

Accepted: November 16, 2021

Published: November 19, 2021

Copyright $\odot 2022$ by author(s) and Scientific Research Publishing Inc. This work is licensed under the Creative Commons Attribution International License (CC BY 4.0).

http://creativecommons.org/licenses/by/4.0/

\begin{abstract}
Using as a stepping-stone The Book of Memory by Zimbabwean lawyer and novelist Petinah Gappah, I set out in this research article to grapple with the dynamics of the vexed issue of memory. The paper argues that, when it comes to memory, the individual intertwines with the collective. Even though the act of remembering is purely individual, the fact remains that it is enacted in a social context with groups acting as cues. Remembering is not an isolated act. Instead, it is group-induced. The article also brings to light the crippling weaknesses that memory studies have long suffered from, namely the short shrift given to the collective dimension in favour of the personal. It follows from the research project, though, that this flaw began to be remedied with the seminal of work of the French sociologist Maurice Halbwachs who introduced the concept of "collective memory" to foreground the communal nature of memory. What the French thinker calls "social frameworks", the paper explains, reflects the social contexts in which people remember. The politics of memory works at many levels, with forgetting being dubbed by Aleida Assman a "social normality" and remembering the "exception." From a methodological perspective, I elected to adopt an approach based on the humanities, and the social sciences, not least sociology and history, in order the better to bring into sharp relief the dynamics of memory.
\end{abstract}

\section{Keywords}

(Collective) Memory, Forgetting, Remembering, Caring, “Othering," Difference, Identity

\section{Introduction}

The purpose of this research paper is to grapple with the vexed issue of memory. 
Two reasons basically underpin my choice of memory as a subject within the framework of this investigation project. For starters, it's the significance of memory to the meaning of life. Memory, albeit something that is no more, can be of huge help when it comes to managing the needs of the present, and considering the future. Secondly, the academic interest in exploring the politics of memory in African fiction in English. Much as sociological and anthropological works on memory abound, viewing it through the lens of fiction helps reveal other facets of the notion bear testimony.

A thorough reading of the body of literature about the issue of memory reveals it to be very contentious. A quick review of some of the definitions related to "memory" will, doubtless, help have a better handle on it. Amongst the slew of definitions that The Oxford Advanced Learner's Dictionary gives to the word, one is relevant to the topic: "a thought of something that you remember from the past" (Eighth edition). A renowned German sociologist and a leading pundit on memory theory, Jan Assmann describes the term thus:

Memory is knowledge with an identity-index. This is not to say that this knowledge is all about oneself; on the contrary, it refers to all kinds of things of the outward and inward worlds, but with a strong link to an idea of "self" that accompanies this knowledge and sets it off against normal, identity-neutral knowledge. (Assmann, 2008a)

The pith of the foregoing quotation lies in the fact that it foregrounds a two-pronged dimension of memory that is, a personal cum a collective edge. In the preface to Social Memory, a signal book edited by James Fentress and Chris Wickam, I. Moor provides a definition of memory that captures its complexity and, perhaps more significantly, emphasizes how the present and the past are interwoven: "it [memory] is an artefact and a trickster, and an active trickster at that, not merely a relic of the past, but the past shaped and adapted to the uses of the present and of the present then as well as now" (Qtd. in Fentress \& Wikham, 1992). Deserving elaboration is the point that memory both appertains to the personal and the collective. From a purely sociological perspective, the individual and the whole merge into oneness. The dividing line between personal memory and collective memory is extremely thin to the point of effacing. Assman and Czaplicka write that: "Every individual memory constitutes itself in communication with others. These 'others', however, are not just any set of people, rather they are groups who conceive their unity and peculiarity through a common image of their past" (127). Hence the term "collective memory" which describes "the interplay of present and past in socio-cultural contexts" (Erll \& Nünning, 2008).

The origins of collective memory stretch back to the early twentieth century with the French sociologist, Maurice Halbwach, as its brainchild (Erll and Nünning, 2008). In a seminal book published in 1925, and entitled Les cadres sociaux de la mémoire, the famed French sociologist lays out the significance of social contexts to memory which, in his estimation, really occurs through interactions 
amongst groups with shared past experiences. Halbwachs's take on the meaning of memory is nothing but a counter to psychologists' proclivity for regarding people as isolated beings (Halbwachs, 1992). This perception, he argues, does not hold water as any understanding of mental operations would necessarily mean sticking to people and severing the bonds between individuals and their fellows in society (Halbwachs, 1992, Trans.). He points out the impossibility of fathoming out the working of memory by divorcing people from society:

If we examine more closely how we recollect things, we will surely realize that the greatest number of memories to us when our parents, friends, or other persons recall them to us. One is rather astonished when reading psychological treatises that deal with memory to find that people are considered there as isolated beings (...) Yet it is in society that people normally acquire their memories. Yet it is also in society that they recall, recognize, and localize their memories. (Halbwachs, 1992)

What Halbwachs calls the "social frameworks" of memory inscribes recollection of past experiences in a kind of call and response exercise between an individual and the group to which they belong. Actually, for an individual to be able to efficiently recall, they need help from their group members: "Most of the time, when I remember it is others who spur me on; their memory comes to the aid of mine and mine relies on theirs" (Halbwachs, 1992). Group membership gives memory a collective edge. The impossibility of individuals to recollect in isolation locates memory in sociality, and, more significantly, bespeaks the commonality of lived experiences within specific social groups. It's noteworthy that since Halbwachs, diverse terms have been floated to describe the materiality of memory. One such terms is "social memory," which is the brainchild of art historian Aby Warburg (Fentress \& Wickham, 1992). They describe social memory as follows:

...we regard social memory as an expression of collective experience. Social memory identifies a group, giving it a sense of its past and defining its aspirations for the future.... It is individuals who do the remembering; what is social about it. The essential answer is that much memory is attached to membership of social groups of one kind or another. (Fentress \& Wickam, 1992)

It follows from the foregoing quotation that much as there obtains personal memory, it still remains that it takes a backseat to collective memory. The Halbwachsian theory that any enactment of individual recall unmistakably necessitates prompting from the collective betokens a conception of memory deeply embedded in the social fabric. Another layer of the social edge of memory is language, for it is by dint of verbal interaction which refers to "a means of both communication and of knowledge" (Moscovici, 2001), that memory is mediated. That is why James Fentress and Chris Wickham feel personal memory to be less objective than collective memory. From their vantage point, there is no better 
way to share past experiences than through the spoken word:

What makes objective memory seem more usable as a source is the fact that we can articulate it. What makes (objective) memory seems more objective than the memory of feelings and personal experience is simply the fact that we can articulate and communicate the former in words, more easily than we can the latter. (Fentress \& Wickham, 1992)

The foremost purport of memory lies in its storage of the past for the sake of the present and the future. Knowledge about its past can shepherd a community through the challenges of the here and now as it looks ahead to the future. The past that memory carries does not simply boil down to a written record of a bygone era. Rather, it is communal and, more to the point, shot through with sacred meaning as it epitomizes the narratives and objects through which a given social group accounts for its existence. Arguably, collective memory or social memory embodies a set of social representations which constitutes,

a set of concepts, statements and explanations originating in daily life in the course of individual inter-communications. They are the equivalent in our society of the myths and belief systems in traditional societies; they might even be said the contemporary version of common sense...the way in which men think or create their shared reality as in the content of their thinking.

(Moscovici, 2001)

It is safe, indeed, to bet that a human community devoid of social representations is soulless. Memory and social representations have a commonality, namely that they are anchored in socio-cultural contexts and are, consequently, communal. At the same time that "individuals and groups create representations in the course of communication and cooperation" (Moscovici, 2001), so too is memory enacted in language, and tied to group membership. The dynamics of memory will be grappled with at a greater length from a fictional perspective, viz., The Book of Memory.

\section{The Book of Memory: A Synopsis}

A breakout debut novel by Zimbabwean writer Petinah Gappah, The Book of Memory came out in 2015. It tells the story of an albino woman, gone by the name of Memory who happens to be the lead character. Her life takes a nasty twist when her parents "sell" her to a wealthy white man. That is, Lloyd Hendricks lived up to the expectations of Memory's parents as he threw everything in the kitchen sink to make her happy. Quite unexpectedly, Lloyd dies at his home. The finger of blame is pointed at Memory. Following what she deems an unfair trial, she is sentenced to death. She chronicles in notebooks (that she shares with the public) her life on death row, other personal woes as well as the rank squalor that plays out in Chikurubi prison. Memory's overnight forceful move from the family seat located in the township of Mufakose whose night is "torn with sounds of couplings, snoring, howling dogs, the running feet of thieves 
chancing it in the darkness" (Gappah, 2015, to the up-market district of Umwinsidale is, in addition to being a psychological gut punch, a momentous game changer. Memory cannot help but feel out of sorts through her helpless inability to tease out the rationale behind what she regards as her parents' ill-advised gesture. She is all the more baffled as her albinism has turned her into something of a plaything within the community. At times spot-on, at times fuzzy and beset with inconsistencies, the protagonist's painful memories reflect, to all intents and purposes, the level of social suck that percolates through every strata of the society.

\section{Language as a Vehicle of Memory}

Patina Gappah's gruesome portrayal of the working of memory bears testimony. The lead character in the story struggles to negotiate a labyrinthine web of painful memories as she goes to great lengths to share with the public the chunks of her own past that she can recall. Memory acts on the advice of her seasoned attorney, Vernah Sithole, to recount to an American investigative journalist her ordeal: "It was Vernah's idea that I should tell my story to you. Before she sent you to interview me, she told me that I should write down every detail that I could remember, that I should record everything that could make a sympathetic case" (Gappah, 2015). Memory's well-meaning call to go public about her own past underscores somewhat the oneness of personal and collective memories. Her personal memories are, arguably, collective as she elects to spin a yarn about them. To be sure, Memory has gone through a hell of a lot of harrowing experiences which mirror a life of injustice and wrongs as well as the cruelty of fate. What features in the recollections of Memory is first and foremost her albino condition, and then the circumstances of her "selling" to a white man. All her ensuing woes are a direct offshoot of her parents' move to relinquish their responsibility to Lloyd.

Prior to her serving time for murder, Memory has had to face stigmatization that borders on dehumanization because of her skin colour. Memory's recollection of her albinism during her childhood speaks to the nefarious discrimination facing albino men and women in society. She recalls being relentlessly being singled out for derogatory taunts, which wrapped up turning her into a peon:

There was a brutal honesty in how children regarded anyone different. If they saw a person with no legs, they did not point out a person living with no legs or a person living with no sight; they shouted, hone chirema, hona bofu $^{1}$, come and see the cripple, come and see the blind man, calling attention to each deficiency.

Their attitude was implicitly rooted in the language itself. ... As a murungudunhu is heavy with meaning. As a murungudunhu, I am a black woman who is imbued with the whiteness of murungu, of privilege, but of dunhu,

${ }^{1}$ The underlined words or phrases are italicized in the book. 
of ridicule and fakery, a ghastly whiteness. (Gappah, 2015)

Memory enacts recollection through language. By the same token, it is by dint of that very medium that she is cast as a social pariah. Scorn and disrespect are inscribed in the unconscionable exclusion and rejection of those suffering from albinism. According to Miroslav Volf, a particular rhetoric goes with the territory of exclusion: "The "practice of exclusion" and the "language of exclusion" go hand in hand with a whole array of emotional responses to the other, ranging from hatred to indifference; these exclusions both call forth emotional responses and are sustained by them' (Volf, 1996). A key prop of exclusion and "othering" is language. The significance of language is basically two-pronged-that is, a means of communication and a "cultural carrier" (wa Thiong'o, 2009). Speaking of the prominently critical role of language in the construction of memory, he says, "Language is the clarifying medium of memory or rather the two are intertwined' (wa Thiong'o, 2009). Plainly, Ngũgı’'s theory is vindicated by Memory when she submits:

I read somewhere that long-term memory is linked to the pre-frontal lobe of the brain, which only develops at the age of three. I also read, perhaps in the same article, that memory is closely linked with the acquisition of language, that without verbal ability to articulate experience, there can be no memory, and this is why our earliest recollections date from the time we learn to speak. (Gappah, 2015)

Consciousness of memory without the ability to articulate it means a thing. One of the vignettes of language lies in the fact that it enables us to overtly open up about our past, thoughts, concerns, woes-you name it. Another silver lining associated with sharing a past experience through verbal communication resides in its "reinstatement" effect upon which Katherine Nelson and Robyn Fuvish elaborate as follows:

"Reinstatement, in effect, "brings back" some part of an experience...The implication of the reinstatement effect is that the "bringing back" reactivates the event in part or whole. It has been frequently speculated that talking about an experience might have the same effect, reactivating in essence the original experience itself on a conscious mental level rather than on an action level. (Nelson \& Fuvish, 2000)

The power of speech, which is a unique human endowment, goes a long towards facilitating recall. For all its usefulness in human life, though, language has the potential of being turned into a potent weapon of oppression and subjection. Witness what happened during colonization. Colonialism rested on an ideology that, inter alia, foregrounded the backwardness of indigenous African languages. That is, a disgustingly despicable form of brainwashing which culminated in the quasi erasure of indigenous languages, and the nefarious imposition of European ones, e.g., English, French and Portuguese. Kenyan prominent man of letters 
Ngữğ wa Thiong'o who has addressed at length in his opus (fictional and nonfictional) the backwash effects of the colonial enterprise on African languages, explains that, "The choice of language and the use to which it is put is central to a people's definition of themselves in relation to their natural and social environment, indeed in relation to the entire universe" (wa Thiong'o, 2009). He speaks of "linguistic encirclement" to describe the trend amongst African writers towards defining themselves in terms of those foreign languages through which Africa have been held in subjugation for centuries. He goes on to point out the end result of the unconscious internalization by African intellectuals and the uneducated alike of the supposed clout of the European languages over their own mother tongues:

English, like French and Portuguese, was assumed to be the natural language of literary and even political mediation between African people in the same nation and between nations in Africa and other continents. In some instances these European languages were seen as having a capacity to unite African peoples against divisive tendencies inherent in the multiplicity of African languages within the same geographic state. (wa Thiong'o, 1986)

If anything, the unflattering plight of African languages left over from the colonial era features in Memory's recollections. Colonization was so gruesome an enterprise that its memory lives on decades after its demise. The lead character takes aim at her white compatriots for their all-out drive to mediate the utter oblivion of indigenous tongues by getting people to buy into the false narrative that the local languages are hard going, and that "they twist the tongue and confuse the mind" (Gappah, 2015). Memory bemoans the lingering effects of what she terms "superior education", namely the short shrift given to local languages in favour of English, to wit, the language of the former colonizing power in Zimbabwe. What sticks in Memory's gizzard is the propensity of white minority for subtly working flat out to bury African linguistic heritage with an eye towards divorcing the indigenous people from their cultural ethos. Quite unexpectedly, Lloyd and his friend Liz Warrender are white folks out of the common run in that they do their level best to achieve mastery of Shona-one of the most important languages in the country. Plainly, there is a calculated rationale behind their "love" of local language, though. Actually, by translating Homer and Aristotle into Shona (Gappah, 2015), Lloyd (who earned a doctorate in Classics) seeks to overwhelm indigenous psyche with Western thought, the end game being acculturation and assimilation. The following sums up how Memory displays her disquiet cum her sense of resentment about the linguistic legacy in a postcolonial African country:

Lloyd's written Shona was much better than mine. My spoken Shona is still fluent, but my writing is frozen at the age of eight which is when I last wrote it in school. This is one of the consequences of a superior education, you 
see. In this independent, one-hundred-per-cent-empowered and fully and totally indigenous blacker-than-black country, a superior education is one that the whites would value, and as the whites do not value local languages, the best-educated among us have sacrificed our language at the altar of what the whites deem supreme. So it was in colonial times, and so it remains, more than thirty years later. (Gappah, 2015)

There is no denying that language impinges on memory in one way or another. As a tunnel through which ways of life are passed down from generation to generation, language helps store and articulate memory. Hence Ngữg’s proposition that the recipe for memory loss is through linguistic erasure: "Language is the clarifying medium of memory or rather the two are intertwined. To starve or kill a language is starve and kill a people's memory bank' (wa Thiong'o, 2009). Frantz Fanon was a high-profile postcolonial pundit. In his wide-ranging writing on the colonial experience and its multifaceted aftermath, he broaches inter alia the critical role of language to the subjugation of a people. He sees eye to eye with Ngữğ: "To speak means to be in a position to use a certain syntax, to grasp the morphology of this or that language, but it means above all to assume a culture, to support the weight of a civilization" (Fanon, 1986). It is worthwhile to emphasize that the colonialist's all-out effort to impose their language on the colonized was anything but empathetic. Instead, it attests to an egotistically stubborn stomach to "construct an elite who shall carry the weight of the colonizer's memory and become the means by which the elite's parents shall lose cultural memory" (wa Thiong'o, 2009). The weakened status of indigenous languages across the Dark Continent vis-à-vis some European languages is nothing short of an insult to African cultural memory. (I'll be expanding upon the concept of cultural memory later on in the paper.)

\section{The Collective Edge to Memory's Remembering}

Interestingly, lots of Memory's memories cut across sisterhood to encompass the citizenry. From her grievances about the rank squalor and the awful inhumanity that hallmark Chikurubi prison, not to mention the pervasive destitution that makes life unbearable for the populace, to the unfairness of the judiciary: Memory's lot is that of Everyman in her country. This doubtless speaks to the collective edge of her memories. Witness how she describes the hellhole of Chikurubi to Melinda Carter, an American investigative journalist to whom she opens up about her past at the urging of her attorney, Vernah Sithole:

For reasons that will be obvious to you, we are not allowed forks and knives. But nor are we allowed to use our hands like normal people. We eat all our food with tablespoons, everything from the waterlogged porridge to the lump-filled sadza and the cabbage that smells of sweat...

There is no happy-medium to our food; it is either overcooked or undercooked, or it has too much salt or there is not enough oil in the fried vege- 
tables or there is so much that you fear that America will invade. (Gappah, 2015)

Indeed, the use of the possessive adjective "our" betokens collective experience. The personal memories of Memory, besides oozing with bitterness born out of injustice, interweave into those of the community to which she belongs. The injustice that reigns supreme in prison facilities is a mirror image of that which plays out outside. The recollection of her spell as an inmate in Chikurubi is not perfunctory. Anything but, her shared experience of solitary confinement is meant to be an eye opening with an eye towards, effecting change for the better. The argument bears emphasizing that the memories that Memory recalls are those that stand out to her in terms of scope and poignancy. Recollections germane to the unfairness of the judicial system and the squalor in prison facilities impinge on the collective as a whole. Memory somewhat speaks on behalf of the collective. Maurice Halbwachs underscores the interplay between individual and group memories: "One may say that the individual remembers by placing himself in the perspective of the group, but one may also affirm that the memory of the group realizes and manifests itself in individual memories" (Halbwachs, 1992). Memory's galling beef about prison conditions and the trinity of bribery, graft and corruption that bedevil the polity, not to mention the legacy of colonization in post-independence African countries, are thrown into sharp relief in her memories. Treated like dirt by prison guards (not the least of whom is Synodia), subjected to sleep or food deprivation over the slightest misbehavior, prison inmates are looked on as the lowest of the low who, consequently, deserve no quarters; they learn the hard way. As Memory clearly remembers,

there was no induction or orientation of any kind. Synodia, Loveness and company prefer to learn by what you might call the Montessori Method of Prison Instructions: you learn by doing, picking things up as you go along. The more mistakes you make, the more they hit you and the faster you learn.

So you learn that a prisoner is allowed to talk to talk to the guards only when she kneels before them. A prisoner may not look directly at a guard...No prisoner is called by her real name. (Gappah, 2015)

Memory's nerve-wracking stay on death row and, more significantly, the phony trial that led to her sentencing represent a past that she has her work cut out drawing a line under. The ground zero for her brush with the law starts with the death of Lloyd. Hence the poignancy that marks the episode of her past life respecting Lloyd, and the circumstances around which she was over handed to a foster father. Although she has experienced extremity-driven crass destitution, and family tragedies with the loss of loved ones, the episode of her life with Lloyd still rankles. Memory waxes indignant as she recalls the offhanded attitude of the judge during her murder trial that resulted in the death penalty being handed down on her: 
In the wood-panelled courtroom, the judge and his two assessors sat on green leather chairs with backs as high as gravestones. The judge spent much of the trial looking into the middle distance. The assessor to his right was asleep. The assessor next to him, a woman of Indian origin, had a face that was twisted into a rictus of concern. (Gappah, 2015)

Notwithstanding the fact that there were no "forensic reports" and "postmortem" to prove beyond a reasonable doubt the culpability of Memory, "the judge concluded that I was guilty of the crime that I was charged with" (Gappah, 2015). The inequity of the judiciary as well as a sense of despondency is writ large in Mnemosyne's recollection of the circumstances of her murder trial, and subsequent sentencing. This episodic memory is all the more excruciating as Memory was tried and sentenced on fake charges, the judge having based his verdict on only one witness-that is, Alexander who turns out to be Lloyd's sister. What prejudices the latter against Memory is her animus against her brother's will, under the terms of which all his property and money should be bequeathed to Memory after his passing (Gappah, 2015). At bottom, Memory has fallen prey, as it were, to quirks of fate. When she returns home one day to Summer Madness, and finds Lloyd dead "with his socks on," she is overrun with shock and dismay. And justifiably so. After unavailingly striving like hell to revive him, she tires. Even though Lloyd "had died accidentally," Memory was desperate to "transform this accident into another type" with a view to "mak [ing] it seem as though he had died in another way" (Gappah, 2015). She put money where her mouth is and decides "to make his death look like he had been shot during a robbery" and then shot him and dropped his body into the pool (Gappah, 2015). Just like that Alexandra appeared out of the blue and witnessed the scene. Needless to say that it was a godsend for Lloyd's sister who could not brook her brother's will in favour of Memory. Upon seeing what Memory was up to, she recoiled and drove away. Memory's frantic attempts to explain to her the scheme drew a blank. The court used Alexandra's testimony as a watertight smoking gun to indict and sentence Memory to death.

This episode in the past of Memory is not recalled just for the heck of it. Not only does it highlight the significance of fate in human life but it also points to human being's crippling inability to forestall the potential fallout of their actions. Good intentions do not always yield the expected results due to forces out of human control. Arguably, fate adds meaning to human existence. Memory remembers Lloyd saying in one of his lectures, "Giving fate a name is a necessary imaginative act that permits us to establish a relationship with the controlling forces of our existence" (Gappah, 2015). Getting a handle on dramatic or unlooked-for turn of events necessitates being steeped in the consciousness of fate. The circumstances that led to Memory's imprisonment, speedy trial and death sentence pronouncement is, indeed, an object lesson in the masterly need to contend with the hand of fate in any human action or 
planning.

The emotional and psychological tinge in the memories of Mnemosyne sound like a wake-up call which emphasizes the driving necessity for people to sit up and take notice. Also, it is tantamount to a stubborn desire to come to terms with a painful past. One of the perks associated with memory is that it draws on the past of the collective to ensure a better present, and envisage the future auspiciously. The relevance of recalling past experiences-whether painful or happy-signals a concern for the present. The utility of the past never wanes as it somewhat acts as a review mirror that could help us swerve the pitfalls of the moment and swerve those that lie ahead. Understandably, memory does not boil down to something of a relic that cannot serve any purpose in the present: "Memory is always a phenomenon of the present, a bond tying us to the eternal present. Memory, being a phenomenon of emotion and magic, accommodates only those facts that suit it" (Nora, 1996). So it would be downright misguided to conceive of memory as a footnote to the present. The deliberate call of sharing publicly one's own past, without seeking to sweep any aspect of it under the carpet, may be an experience worse than death. Yet it can be redemptive: "Even the project of remembering the gloomiest of memories is a hopeful project. It ultimately rejects the pessimist thought that all will be forgotten" (Margalit, 2004). In point of fact, the past is not recalled just for the sake of it; it is so for a reason. Halbwachs positions that "in reality the past does not recur as such, that everything seems to indicate the past is not preserved but is reconstructed on the basis of the present" (Halbwachs, 1992). Thanks to the (collective or social) mediation of memory, the present and the past are forever entangled in a sort of symbiotic relationship that feeds on each other's factual and emotional significance. As the Israeli philosopher Avishai Margalit points out, there is an unimpeachable interest in "remembering emotions as a way of knowing how the things we remember were felt at the time-a way of grasping the sense and the sensibility of past events needed for understanding and assessing the things we care about in the present, especially the people we care about' (Margalit, 2004). In the case of Memory, the sensitivity of her experience of utter squalor, the traumatizing experience of living in the shadows of squabbling parents, and living in the shadows of a mother whose rough edges were way difficult to smooth: all this gives a resentful edge to her recollections.

The lead character's earnest submission that "My memories are not of bygone feasts" underscores yet again the traumatic edge of her past experiences. From the perspective of "lay trauma theory," traumas refer "naturally occurring events that shatter an individual or collective actor's sense of well-being" (Alexander et al., 2004). They go on to posit that anything that precludes human beings' fulfilment of the "need for security, order, love, and connection" is potentially traumatizing (Alexander et al., 2004). From this vantage point, Memory's handovert to Lloyd is, arguably, a trauma. Unsurprisingly, she suffers the memory of it. The memories of Memory highlight, in no small measure, the preposterous 
lousiness of life in the townships where "to be photographed was a commitment that required money and serious effort" (Gappah, 2015). Memory constantly bemoans the paucity of photographs through which she can turn the clock back to her childhood: "I have no pictures that could have helped me remember. I took none with me. My mother's photo album remained with all the other things that I left behind in Mufakose. And even then, even if I had wanted to take some, there were not many pictures in that album" (Gappah, 2015). Memory's evocation in her acts of remembering of the album of her family is not perfunctory. Photographs are symbols of collective memory as they act as triggers of remembering. When the individual sees a picture of them referring to a distant past, they cannot help but cast their mind back to a specific event in the past (Assmann, 2008a). Pictures help us reconnect to significant episodes of our past. According to Jan Assman, although 'things do not "have" a memory of their own, the fact remains that 'they remind us, may trigger our memory' in the sense that 'they carry memories which we have invested into them, things such as dishes, feasts, rites, images, stories and other texts, and other "lieux de mémoire"' (Assmann, 2008a). Harking back to The Book of Memory, the lead character waxes emotional as she tries to conjure up the purport of the said photographs, and goes to great lengths to restore the photo to wholeness: “After everyone had gone to sleep that night, I look for the pieces of the photograph and tried to stick everyone together with my saliva. It did not work. I contemplated stealing sticky tape from the desk of Mistress Nyathi, my class teacher" (Gappah, 2015). Failure to possess photos may be a hindrance to understanding a chunk of one's past, or simply to its erasure. It is for the sake of avoiding erasure of aspects of her past that Memory went out of her way to pick up the pieces of a photograph that her mother tore into pieces in a fit of anguish over the death of Mobhi, a sister of hers. Photographs are part of family memory, and pertain to what Jan Assman calls "cultural objectivations," viz., carriers of memory (Assmann, 2008a). Photography offers a hindsight that gives you a broader picture of what a past event or situation really was. British-born cultural historian, Anne Kuhn, adumbrates the significance of photography and other objects through which cultural memory ${ }^{3}$ is erected into an institution status:

\footnotetext{
${ }^{2}$ The term "lieux de mémoire" is, roughly speaking, a site symbolizing a scared past in the consciousness of a group or nation, and where commemorative practices take place. It is the brainchild of French high-profile historian Pierre Nora who perceives a lieu de mémoire (the original French term) as "any significant entity, whether material or non-material in nature, which by dint of human will or the work of time has become a symbolic element of the memorial heritage" (Nora, 1996). The historian adds that for a site to qualify as site of memory it must be invested with a three-pronged sense, so to speak: material, symbolic, and functional. In the same breath, Nora is emphatic that "will to remember must be present," adding that "without this criterion, the definition would be so broad as to encompass almost every object worthy of remembrance" (Nora, 1996). Examples of sites of memory include cemeteries, museums, archives which he calls "relics of another era, illusions or eternity" (Nora, 1996). A 'lieu de mémoire' is highly symbolic in that it is invested with an aura of what is no more, the here and now as well the future. In a nutshell, a site of memory stands as a huge reminder of an event in history whose importance marked the past, has bearing on the present and helps shape the future.
} 
As repositories of memories, reminders of persons, places or events in the past, family photographs and albums may certainly be regarded as souvenirs. Indeed, while family photos can function prosthetically (sic) as substitutes for remembering, they are also used by their compilers and owners as prompts for performances of memory in private, interactive, collective, and sometimes even public contexts. The performance or enactment of memory in these instances takes place with (as opposed to in) photographs and al-

${ }^{3}$ The concept 'cultural memory' is the brainchild of German academic and Egyptologist, Jan Assmann who happens to Aleida Assmann's husband. Even though Jan Assmann has introduced the concept into memory literature as a counterpoise to Maurice Halbwachs' concept 'collective memory,' he acknowledges in full measure, nonetheless, the famed French sociologist's seminal contribution to putting the social dimension of memory into the foreground of memory theory: "It was the great achievement of the French sociologist Maurice Halbwachs to show that our memory depends, like consciousness in general, on socialization and communication, and that memory can be analyzed as a function our social life" (Assmann, 2008a). With his coinage of the concept of cultural memory (which came along over twenty years ago), Jan Assmann picks some holes in Halbwachs' term, and, in the same breath, 'delineate [his] concept of "collective memory" and our understanding of "cultural memory" (Assmann, 2008a). Jan Assmann holds that Halbwachs did not take account of "the real of traditions, transmissions, and transferences" in theorizing "collective memory." As if remedying a weakness, he puts this three-pronged realm under the category of what he calls "cultural memory." $\mathrm{He}$ is at pains to underline the commonality between the two concepts which, incidentally, blurs the lines: "Cultural memory is a form of collective memory, in the sense that it is shared by a number of people and that it conveys to these people a collective, that is, cultural, identity" (Assmann, 2008a). Indeed, Jan Assmann seeks to take into account the cultural dimension which, in his estimation, Halbwachs overlooked in his analysis of memory (Assmann, 2008a). To this effect, he goes the extra mile and splits Halbwachs' term into two: "communicative" and "cultural memory." Subsequently, he attends to the dividing line between these two concepts. After labelling "cultural memory" an institution, he sums up nuts and bolts as follows: "It [cultural memory] is exteriorized, objectified, and stored away in symbolic forms that, unlike the sounds of words or the sight of gestures, are stable and situation-transcendent: they may be transferred from one situation to another and transmitted from one generation to another" (Assmann, 2008b). Speaking of "communicative memory," he, at first glance, spots a key aspect that marks it off from "cultural memory," namely that it "is non-institutional." He elaborates thus: "it is not supported by any institutions of learning, transmission, and interpretation. It is not cultivated by specialists and is not summoned or celebrated on special occasions; it is not formalized or stabilized by any forms of symbolization; it lives in everyday interaction and communication." This distinctive facet means that "it has only a limited time depth which normally reaches no farther back than eighty years, the time span of three interacting generations" (Assmann, 2008b). Examples of "collective memory" include monuments, museums, cemeteries-you name it. Instances of "communicative memory" encompass oral myths, rituals, masks -and what not-. In The Book of Memory elements of "communicative memory" in terms of oral myths and traditional beliefs abound. What is termed "ngozi" and "njuzu" are cases in point. The two terms feature in the memories of Memory as crucial to In Zimbabwean mythology. Mindful of extraneousness of these words for a Westerner, Memory has a hell of difficulty explaining them to the American journalist Melinda Carter to whom her memories are addressed in epistolary form. (By opening up about her past experiences to an investigative journalist, she hopes for their dissemination, thereby evidencing the collective dimension of her memories. Talking about the trickiness of njuzu, she says: "I am not sure how to explain njuzu to you; there is no direct equivalent in your mythology" (Gappah, 2015). She likens them in layman terms to mermaid or water sprite, except that they outpace them in violence and badness. Then she dwells on the evil nature of the said mythical creature: "Njuzu are violent, they are wild beyond taming. ... They become hurricanes and storms. They transform into snakes and crocodiles. Njuzu capture the unwary and pull them down... They are especially fond of children" (60). Speaking of "ngozi", they are, in light the mythology, endowed with such destructive powers as to strike the fear of God into people: "Ngozi, if you did not already know, is the spirit of vengeance that follows a violent death" (Gappah, 2015). Interestingly, the prominence of ngozi in the memories of Mnemosyne lies in the fact that it has taken a heavy toll of her family. Memory recounts on pages how her mother the wife of her first husband. It all came about, she explains, when "an ancestor of my mother had killed an ancestor of her first husband." In a move calculated to appease "the spirit of the dead man" who "came back as an angry ngozi spirit and wreaked havoc on my mother's family," Mnemosyne's was intimated that the debt had to repaid. "Repayment" was all the more necessary since "fields failed to prosper, children rotted in their mother's wombs" (Gappah, 2015). It was against this portentous background that a settlement was reached which turned out to be fatal to Memory's mum: "Her family had decreed that that long-ago death had to be honoured through the gift of a girl to the family of the murdered. My mother was to be the currency that paid the debt" (Gappah, 2015). Memory's mother's choice to elope with her 'second' husband, to wit, Memory's father, was the logical upshot from a marriage that was doomed to failure from day one. That is, it was a forced marriage. So Ma'Givhi flew into the arms of Ba'Givhi as she sought succor and, perhaps more significantly, refuge from the emotional and physical ravages of unrequited love, and shotgun marriage. The lingering "anger" of the ngozi reached fever pitch with the violent deaths of Memory's parents the cause of which, though not revealed openly, points to suicide. The suddenness of the deaths made Memory think of a mutual suicide agreement. Myths provide a window into a community's worldview and reference points embedded in time-honoured stories, and the sacred store that they set by it. This sacredness implies that any breach of those invites the wrath of evil spirits. As Hayden White says, "Myth emploits (sic) stories about specific actions and sets of events as manifesting the consequences of violations or observances of the rule ot propriety" (White, 2000). The retribution that befalls trespassers serves a deterrent to the community across the board. Culture intertwines with history in myth. Therefore, Stories of myth, arguably, sanctify a past tinged with an aura of sacredness and inviolability. 
bums. (Kuhn, 2007)

Understandably, Memory's frustration with the issue of family photographs is downright excruciating. They are part and parcel of her past as a young albino girl whose 'othering' have packed a punch in terms of mental distress, and whose parents have strenuously struggled to put food on the table owing to trying times. The prominence of family photography and albums alike as a silent but potent articulation of memory resides in its authenticating a lived experience, painful or otherwise happy. Hence Anne Kuhn's use of the word 'evidence' to characterize one way amongst many through which a photography or album can be approached (6). From Memory's vantage point, the availability of family photographs is supposed to help reconstruct a past that is a far cry from her here and now. The more so since "at the moment of reproducing the past our imagination remains under the influence of the present social milieu" (Halbwachs 49). Memory survived a past (which doomed her to disappearance) in the face of overwhelming odds. No matter how somber and gruesome this past may be, she does not want to draw a line under it look, line and sinker due to its aura of emotional charge. Maurice Halbwachs roughly explains the rationale for some people's stubborn attraction to the most difficult period in their lives:

When it comes to the most somber aspects of our existence...it seems they are enveloped by a cloud that half cover them. That faraway world where we remember that we suffered nevertheless exercises an incomprehensible attraction on the person who has survived it and who seems to think that he has left there the best part of himself, which he tries to recapture. (Halbwachs, 1992)

The family is something of a breeding ground for values and ways of life as well as patterns of behaviour that make up identity, and, by extension, produces memory; it is a locus of collective memory. The blood ties and the everyday interactions between members living in the same familial space known as household contribute to foster and cement understanding within the domestic group (Halbwachs, 1992). As a result, the somber and pleasurable events that occur in family life are seared in the memory of the household. An individual always badly needs a memento through which they can turn the clock back to their domestic life as a token of family memory. Needless to say then that Memory is not a happy camper about the paucity or absence of souvenirs that connect her to her familial past. The unpleasantness of this situation hits home when visiting in a site of memory or when she hears about somebody else's family remembrances:

Sometimes, when I found myself in the Archives, or when Lloyd talked about his family, I thought of my own, undocumented past. The parents that I left behind in Mufakose seemed...to have had no father and mother. We seemed...to be completely unconnected to anyone but ourselves, to 
have emerged complete into the present without a history. There were no old letters, no mementos, no links to any kind of past. (Gappah, 2015)

An individual's drive to retrieve their family past can successfully pay off when there exist written or photographic records of it or when its narrativization can be mediated. Let's face it, none of these mediums of enacting family recall is, to all intents and purposes, handy to Memory. She confesses meltingly that "Even when we asked them, my parents answered no questions about their past." She puts a personal spin on her parents' attitude: "It was more than a lack of openness it seemed an almost active secrecy" (Gappah, 2015). This "almost active secrecy' can be equated with what Aleida Assman calls 'active forgetting' (which I'll be elaborating upon later on.)

Pretty much throughout the narrative, Memory has laboured under the misapprehension that her parents divested themselves of her like goods in return for payment in kind. Consequently, due to absence of cast-iron proof buttressing the act of selling, I think fit to put the verb "sell" in inverted commas. The crux of the matter is that she saw money change hands between the white man and her father-or rather between Lloyd and her mother-, put two and two together and mistakenly jumped to the conclusion that she was sold. Any lingering doubts as to her fate were laid to rest when Lloyd Hendricks made this pledge to her parents: "I will pick her up at twelve tomorrow... I am glad that tour wife approves, because I could not have done it otherwise" (Gappah, 2015). Just like that,

He took something from his pocket. It was a large wad of green bills, twenty-dollar bills; ... He handed the money to my father, but it was my mother who reached out to take it. She took the money without counting it and stuffed it into her bra (Gappah, 2015).

Towards the end of the story, however, the scales fall from Memory's eyes, and the cloud of mystery that has long surrounded the circumstances of how she has wrapped up in Lloyd's hands Lloyd begins to dissipate. It all started when Lloyd, full of the milk of human kindness, offered his help to Memory's father with a view to extricating them out of the crass destitution facing them. The family predicament was compounded by the mother's mental issues which saddened Lloyd big time. Understandably, he suggested that Ba'Givhi send the kids to school so that Ma'Givhi, who "was ill, dangerously ill," could be taken care of, going as far to put him in touch with a friend of his (Gappah, 2015). But because of Memory's indifferent health, Ba'Givhi couldn't act on Lloyd's advice. Upon getting briefed about Memory's condition, Lloyd said that "he would take me in, [and] that he would look after me until my mother was well" (Gappah, 2015). The blueprint fell through with the sudden passing of Ma'Givhi and Ba'Givhi. Thus Memory's assertion that "I was never meant to live with Lloyd" (Gappah, 2015) rings true. In an emotional one-on-one with her sister Joyi, Memory brings herself to admit to labouring under a delusion: 
...I wanted to go back, to see where I made that fatal mistake. My mind keeps going back to that memory of seeing Lloyd hand over the bills, a false memory on which I have built the foundation of my life, or, to put it more accurately, a true memory from which I have made false assumptions. My utter conviction that my parents sold me rested only that exchange of money. (Gappah, 2015)

Deserving elaboration is that the unstable nature of memory, and its often unfaithfulness to the past factor into Memory's difficulty in getting a handle on why her parents have relinquished their responsibility to her in favour of a white man. Speaking of the unreliability of memory, it is safe to assume that remembering is not always a sure-fire way of reconstructing an accurate image of the past. The fact of the matter is that memory is faced with a good many challenges that account for its unreliability, and consequently, its possible faultiness. Aleida Assmann lays out some of the multifaceted strictures which are mainly scientific and cultural in nature-that sometimes cause memory to be unreliable:

Memory capacity is limited by neural and cultural constraints such as focus and bias. It is also limited by psychological pressures, with the effect that painful or incongruent memories are hidden, displaced, overwritten, and possibly effaced. ... As in the head of the individual, also in the communication of society much must be continuously forgotten to make place for new information, new challenges, and new ideas to face the present and the future. (Gappah, 2015)

Indeed, memories go fuzzy with the relentless flow of time. Also, failure to invest a lot attention to an event may make its recollection way difficult to the point of leading to a false interpretation of it. Aleida Assmann's terms of 'focus' and 'bias' reflects, as stated earlier, the vagueness of remembering and, equally significant, its selectivity. Amongst the flood of memories which are up for recall, we found ourselves compelled, for one reason or another, to pick and choose those that are more relevant to our present needs, and leave out the rest when it comes to the crunch. The distinctively selective dimension of memory stands out in relief through the lead character's global appreciation of Lloyd. As the narrative nears its end, and as her misguided perception of the exchange of money between Lloyd cum her parents has sunk in, Memory displays eclecticism as to what she ought to remember respecting Lloyd. With the benefit of hindsight, she overlooks the negatives of her foster father and, instead, zeroes in on his positives, e.g., his "warmth, generosity, and his shining goodness" (Gappah, 2015). And confesses earnestly that she grieves for Lloyd more than she does for her own parents: "I find I grieve my parents as remembered persons. But it is for what I have been long accustomed to that I grieve the most. It is for Lloyd that I grieve the most" (269). Notwithstanding, she says equally genuinely that she bears no ill will for her father because of his handing her over to Lloyd was a leap of faith (Gappah, 2015). 
Interestingly, the fact that Memory cherishes the memories of Lloyd even after his passing betokens an obdurate desire to stay connected to the deceased. It is a way, albeit odd, for the bereaved to enact a maintenance of the relationship with their loved one. This attitude is what American psychologist Dennis Klass et al. call 'continuing bond' in Continuing Bonds. New Understanding of Grief, which goes with the territory of grieving. They posit that "the resolution of grief involves a continuing bond that the survivor maintains with the deceased" (Klass et al., 1996). Memory's strong attachment to Lloyd is anchored in a profound sense of gratitude which she can't help acknowledging: "He gave me an understanding that took me outside of myself, that there was a life beyond things, there was an existence that went on long after the self had gone" (Gappah, 2015). Thanks to Lloyd, Memory was, actually, able to overcome her crippling selfconsciousness about her albinism which made her keep herself to herself during her childhood and early teen years. By somewhat ploughing a lonely furrow in 'continuing bonds' through mental reenactment of her past experience with Lloyd, she proves herself right.

\section{The Searing Memories of "Othering"}

Memory has had more than her fair share of raw deal from life. She recalls being given a wide berth wherever she goes owing to, horror of horrors, the sensitivity of her skin which marks her off from normal people. Memory's albinism-related woes is a window into the plight of albino women and men regarded as social misfits through no fault of their own. Mnemosyne-the only character in the narrative that calls her 'Mnemosyne' is Lloyd probably because of his strong passion for classics-suffers the double yoke of being different from the rest of her community due to her skin colour, and the straightjacket of patriarchy that makes women subservient to men owing simply to their "womanness".

"Othering" is a form of reification predicated upon a misguided conception of difference. Ruth Lister describes it as "a process of differentiation and demarcation, by which a line is drawn between 'us' and 'them' between the more and the less powerful and through which social distance is established and maintained" (Lister, 2004). However, what such subservient groups as albinos go through in terms of stigmatization and rejection fits Schwalbe et al.'s definition of 'oppressive othering' which "occurs when a group seeks advantage by defining another group as morally and/or intellectually inferior" (Schwalbe et al., 2000). Over and above the myth-tinged shibboleths associated with albinism, victims are made to feel unable to prove their worth. Conventional wisdom locates their 'good-fornothingness' status in congenital deficiency. 'Oppressive othering' foregrounds difference as 'unabling' since it "commonly entails the overt or subtle assertion of difference as deficit' (Schwalbe et al., 2000). In her recollection of her past as an albino woman, Memory pushes back on the lop-sided categorization of albinos as a bunch doomed forever to be low performers. (I'll come back to this facet of Memory's portrayal later on.) 'Othering' is a roundabout way of turning dif- 
ference into an unconscionable tool of exclusionary practice. Paul Varo Martinson posits the significance of difference by contrasting it with what he calls the "common":

We must always be alert to difference. The common makes relationship possible, difference makes it significant. Generally, people do not give their lives for that upon which we all agree or find we have in common. People give their lives because of that which is different. Difference is fraught with significance. (Martinson, 2004)

The trope of difference, and its attendant multifaceted human toll features prominently in the recollections of Memory. In addition to the psychological wounds of "othering" that she and fellow albinos experience, there is the white versus black divide that makes indigenous people feel like strangers in their own country. The blatant injustice that the lead character seeks to highlight is about, inter alia, land ownership which is heavily weighted in favour of the white minority. Witness how Lloyd's sister, Alexandra, substantiates away failure of black people to husband the land that they inherited from whites in the aftermath of the land reform program:

Alexandra believed that it was not inexperience that made black people incapable of being farmers, but something intrinsic to their identity. For her, the ability to farm had nothing to do with access to loans and cheap labour, but everything to do with genetic accident of whether you were born white or black. 'African can only farm communally, you see; they can't do the big farming. They are used only to little pieces of land. It is a miracle they grow anything at all. (Gappah, 2015)

Doubtless, these comments reek of racism embedded in an ideology that regards non-white people as barbarians. The purport of Memory's recall of Alexandra's statements lies in the fact that it is a throwback to colonial oppression. In the eyes of the colonialist, black and coloured folks are benighted, thereby requiring to be civilized as a way to enter history. A leading post-colonial theorist, Martinique-born French thinker, the late Frantz Fanon holds that one of the hallmarks of colonization pertains to its construction of the indigenous as devoid of history altogether: "Colonized society is not merely portrayed as a society without values. ... The native is declared impervious to ethics, representing not only the absence of values but also the negation of values. He is, dare we say, the enemy of values. In other words absolute evip' (Fanon, 2004). The full scope of the disdain that the white man harbours for the black person is encapsulated in Alexandra's obnoxiously racist posturing. Memory looks to sharpen our memory of an awfully gruesome chapter in the history of black people across the board, nay of humanity, which, in words of one syllable, amounts to what Jeffrey C. Alexander et al. (2004) dub 'cultural trauma.' He elaborates as follows:

Cultural trauma occurs when members of a collectivity feel they have been 
subjected to a horrendous event that leaves indelible marks upon their group consciousness, marking their memories forever and changing their future identity in fundamental and irrevocable ways.

Colonial trauma is seared forever in the memory of Africans and those of the diaspora as its lingering effects impact big time the lives of millions of people in formerly colonized societies. This decades after colonization came to an end. The present-day political, social and economic make-up of the Dark Continent is in part shaped by the colonial experience, so that African leadership governs through the lens of former colonizing powers. There is, indeed, an internalized complex of inferiority that grips the leadership to the point of blinding them every inch to the herculean task of addressing post-independence challenges. The crippling mindset of post-independence African leadership is highlighted in sharp relief in the memories of Mnemosyne. When white Zimbabweans are on the receiving end of robbery or fatal burglary, their black countrymen are pointed at as villains of the piece. Memory recalls the hasty conclusion tinged with racist overtones that Alexandra jumped to (following two cases of robbery as well as fatal shooting targeting Zimbabweans of white stock), and the subsequent indiscriminate, harsh punishment randomly meted out to some easily identified Zimbabweans:

Alexandra was convinced that the squatters from the camp that had sprawled out on Liz Warrender's property were behind it. In one of the robberies the white couple that lived at the targeted house had been shot and their bodies thrown in the swimming pool. 'Inside jobs,' Alexandra had said, nodding in the direction of the squatter camp. The police had taken some of the squatters away, had beaten them senseless, but no one had confessed, she said. (Gappah, 2015)

Taking a jaundiced view of the supposed culprits' refusal to confess, Alexandra urges her brother Lloyd to keep his powder dry just in case: "Mind you don't pass that lot at night... And make sure you load the gun" (Gappah, 2015). Come to think of it, the salience of Memory's recall of Alexandra's racist slur resides in its withering indictment of the ideological axiom of whites' haughtiness vis-à-vis black people and, more to the point, in it being a tribute to the redemptive value of post-colonial writing project. In reply to Alexandra's scornful submission that "It's the wrong people at the top... You always choose the wrong leaders," Memory comes back with a quizzical retort that cuts Alexandra down to size: "And Ian Smith," I said. “What was he, the white Mandela?” (Gappah, 2015). Thereupon, Alexandra sort of votes with her feet. (Ian Smith is a testament to the horrors of British colonization of Rhodesia, modern-day Zimbabwe.) The colonial hue of the memories of Memory feels like a clarion call to people of black descent to challenge any claim to white cultural purity, at the same that it foregrounds the necessity to fight tooth and nail against erasure or rewriting of the past from white perspective. Remembering colonialist discourse that resulted in 
the human devastation wrought by the colonial enterprise can also be read as a call to black people across the board to assume their status as subaltern groups while being proud of their blackness. An Indian academic, linguist and English professor, Rukimini Bhayo Nair vindicates Memory's clear-sightedness in bringing up the colonial enterprise in her remembering: "Postcoloniality is a condition requiring cure, and the passage to that cure involves a return to buried memories of colonial trauma” (Nair, 2002). She goes on to contend that: “...to understand how the postcolonial self differs from other selves who people the late twentieth century, it could be strategic to begin by exploring that infantile period, colonialism, which by definition preceded the convulsions of postcoloniality" (Nair, 2002). One sure-fire way to avoid postcoloniality being 'assigned to oblivion' is to keep the memory of colonialism and its attendant ravages vivid. This is not to be construed as a thoughtless choice to live in a time warp. Rather, it serves as a potent reminder of man's capacity for evil, and of the necessity for inclusion versus exclusion.

\section{Memory and Identity}

The colonial facet in the memories of Mnemosyne invites another interpretation: the close-knit connection between memory and identity. Oyserman et al. describe 'identity' in a way that captures its link with memory:

Identities are the traits and characteristics, social relations, roles, and social group memberships that define who one is. Identities can be focused on the past-what used to be of one, the present-what is true of one now, or the future-the person one expects or wishes to become, the person one feels obligated to try to become, the person one fears one may become. (Oyserman et al., 2012)

The identity of the self or the collective intrinsically appertains to the past. Values and belief systems are forged through lived experiences, and then transmitted from generation to generation by means of language. The memories of our lives are crucial to our identity as they point to patterns of behaviour or shared experiences that define us in one way or another. The point bears stressing: the past serves as a useful signpost to self-image, whether it be personal or communal. Just as memory is conspicuous by its malleability born out of its natural unfaithfulness to the past, so is identity a perpetual quest for fixity, stability, purity. In this sense, cultural theorist Stuart Hall is at pains to point out that "identities are about questions of using the resources of history, language and culture in the process of becoming rather than being" (Hall \& du Gay, 1996). The 'process of becoming' is a measure of the unstable cum fragmentary characteristic of identity (Hall \& du Gay, 1996). The ever-changing nature of identity coupled with its purport in terms of social memory goes hand in hand with a constant reinterpretation and reconstruction of the past. According to Maurice Halbwachs, sacred storage of the watershed moments of our lives is not 
a perfunctory activity. Instead, it reflects a need to not lose track of our individuality: "We preserve our memories of each epoch in our lives, and these are continually reproduced; through them, as by a continual relationship, a sense of our identity is perpetuated" (Halbwachs, 1992). Harking back to my point as to how Alexandra's racist strictures on black folks is driven by the race-based ideology of colonialism, this much is certain: the colonial enterprise is forever inscribed in the ethos of African cultural identity since it has impinged out of recognition on black self-definition. Plainly, it is the hallmark of colonization as a collective trauma for black people from Africa and the diaspora that makes it a standout facet of African cultural identity. Speaking of cultural identity ${ }^{4}$, Stuart Hall signally contends that there is a two-pronged approach to analyzing cultural identity. The first, he says,

defines 'cultural identity' in terms of one, shared culture, a sort of collective 'one true self', hiding inside the many other, more superficial or artificially imposed selves, which people with a shared history and ancestry hold in common. Within the terms of this definition, our cultural identities reflect the common historical experiences and shared cultural codes which provide us, as 'one people', with stable, unchanging, and continuous frames of reference and meaning, beneath the shifting divisions and vicissitudes of our actual history. (Hall \& du Gay, 1990)

The memory of racial oppression is a distinctive feature of African cultural identity. Any reference to the colonial experience (whether in thought or verbally) unavoidably twists the knife into the wounds of its human toll whose lingering effects still bruise African consciousness. In the world of The Book of Memory, the interplay between memory and identity also shines through what Aleida Assman calls the 'canon' and the 'archive."' These, according to Aleida Assmann, are the two modes of cultural memory. When she comes from overseas with a

\footnotetext{
${ }^{4}$ The second strand to Hall's definition of 'cultural identity' captures its dyadic nature: "becoming" and 'being." It informs both the past and the future. Hall writes that: "It [cultural identity] belongs to the future as much as to the past. It is not something which already exists, transcending place, time, history and culture." Instead, argues the prominent theorist "Cultural identities come somewhere, have histories" (Hall \& du Gay, 1996). This second sense has a commonality with memory in which "unlike everything that is historical, they undergo constant transformation" (Hall\& du Gay, 1990). Arguably, the histories of cultural identities came about through painful as well as happy experiences. In the case of Africans and those of the diaspora, the paramount feature in their cultural identity traces its lineage to the transatlantic slave trade and colonization, when their ancestors were made to internalize their supposed subservience to white people, accept, through an-out destructive onslaught on their psyche, that they were not worthy of human dignity.

${ }^{5}$ In a most amazing article, German academic, professor of English and Literary Studies all into one, Aleida Assmann, in her discussion of cultural memory the critical prominence of which she and her husband Jan Assmann have contributed to a great deal, brought up two terms crucial to have a better handle upon the politics of "communicative memory"-that is, 'canon and 'archive.' Right from the word go, Aleida posits the unavoidability of forgetting in human life and, consequently, its linkage with 'remembering.' Human beings' inability to escape the trap of forgetting is encapsulated in Aleida's assertion that "When thinking about memory, we must start with forgetting" since "the dynamics of individual memory consists in a perpetual interaction with remembering" (Assmann, 2008a). Locating humans' natural propensity for forgetting in such cultural and cognitive strictures as 'focus' and 'bias,' the German pundit comes up with a two-pronged edge to the phenomenon of forgetting: active forgetting and passive forgetting. Whilst the former refers to "intentional acts such as trashing and destroying," the latter describes "non-intentional acts such as losing, hiding, dispersing, neglecting, abandoning, or leaving something behind" (Assmann, 2008a). It is safe to argue that, in The Book of Memory, it is "passive forgetting" that plays out in Lloyd's attitude to Memory. Actually, the latter's foster father has served jail time as a result of betrayal by Memory. This despite Lloyd's sympathy and, more importantly, beneficence to her. When she returns home one day and sees Lloyd sodomizing Zenzo (an artist for whom she has a soft spot), Memory felt hurt big time. Overwhelmed with grief and jealousy that blinded 1.
} 
degree in art history, Memory's foster father suggested that she contemplate applying for a teaching position at the University of Zimbabwe. But, against her better judgment, she "chose to volunteer at the Archives instead, while I decided what to do" (Gappah, 2015). Her visit to the Archives, courtesy of Lloyd, features as one of her most important of her memories. Witness the elements that she recalls hand-picking for viewing:

I was curating an exhibition of photographs for display at the National Gallery. I selected my pictures: the first young woman to get a medical degree in Rhodesia, market women in Mbare in the fifties, colonial wagons pulled by a team of zebras, naked warriors from the 1896 rebellion hanging from trees, southern fruit in the Rhodesian bush. (Gappah, 2015)

Memory is deeply steeped in the consciousness of what her country has gone through in terms of racial oppression. Her preference of a spot in the Archives as opposed to an academic career is indicative of a soul struggling to find closure with regards to the country's experience of colonial oppression which, disappointingly, is mediated by a stubborn rejection of acceptance of difference.

Difference should be celebrated as opposed to being used to obnoxious ends. The derogatory taunts that the likes of Memory run through the gauntlet of, are intended to overtly and knowingly to make them aware of their 'unbelonginness', their unflattering 'outsider' status. As a result, they wrap up developing low self-regard and diffidence in their competence, and capability to make something of themselves. Memory is on the receiving end of what Moroslav Volf, a

\footnotetext{
Lloyd's generosity, Memory wrote an anonymous letter to the police to squeal on her foster father. Following the latter's arrest, Memory is overcome with remorse. Unable to endure the pricks of conscience induced by betrayal of Lloyd, she goes out her way to secure a scholarship which she brazenly regards as a 'refuge." Unfailingly, the chickens of her betrayal come home to roost when she comes back to her country, graduated from Sidney Sussex University. In light of the past, she expected Lloyd to refuse to give her the time of day. Surprisingly, he welcomes her back with open arms. The fact that Lloyd is so forgiving as to refrain avenging himself on her puts Memory to shame: "How would I overcome the constraints that had arisen between us, how would I cross the distance of all those years? I did not know how to begin to tell him to tell him all the things that I wanted to say; how to tell him that I was sorry for my betrayal' (Gappah, 2015). Lloyd's no-nonsense choice to go down the path of forgiving is sure-way to put a past of suffering behind. From the perspective of the sophisticated Croatian theologian Miroslav Volf, "non-remembering" is crucial to mediating reconciliation: "... since no final redemption is possible to without the redemption of the past, and since every attempt to redeem the past through reflection must fail because no theodicy can succeed, the final redemption is unthinkable without a certain kind of forgetting" (139). The same Janus-faced dimension of forgetting, Aleida Assmann explains, holds true for 'remembering,' except that remembering, unlike forgetting which "is a normality of personal and cultural life," is "the exception which (...) requires special and costly precautions" (Assmann, 2008a). The precautions come in the form of what she calls 'cultural institutions.' Aleida is at pains to show how the two-faced dimension of remembering an active and passive side are critical to grasping the workings of cultural memory. Aleida Assmann goes on to illustrate the meanings of the two by, first and foremost, foregrounding a key difference: "The institutions of active memory preserve the past as present [emphasis in original] while the institutions of passive memory preserve the past as past' (Assmann, 2008a). She elaborates upon the 'canon' and the 'archive' by taking the example of a museum. A museum, she explains, exhibits its high-value objects to the public, which are laid out in such a way as to catch viewers' eyes and attention. Aleida adds that in the same museum, there exist storerooms such as cellars and attics housing painting and objects which are not displayed publicly (Assmann, 2008a). She defines the 'canon' as "the actively circulated memory that keeps the past present," and the 'archive' as "the passively stored memory that preserves the past past" (Assmann, 2008a). Fall under the category of active cultural memory are monuments, and such elements as "normative and formative texts, places, persons, artefacts and myths" whose characteristics lie in the fact that they are designed "to be actively circulated and communicated in ever-new presentations and performances" (Assmann, 2008a). It's noteworthy, however, to contend that not any text belongs to the "canon." For a text to qualify for canonization, it has to be sacred. Assmann gives as instances of sacred texts Shakespeare's plays. I would add such religious texts as the Koran, the Bible and the Torah. Conversely, examples of passive cultural memory are archives of data whose significance Aleida Assmann underscores thus: "Without extended archives of data, there is state bureaucracy, no strategy to organize the future, and no control over the past" (Assmann, 2008a).
} 
high-profile thinker and theologian of Croatian extraction, dubs "symbolic exclusion", namely "a distortion of the other, not simply ignorance about the other." He further argues that it "is a willful misconstruction, not mere failure of knowledge" (Volf, 1996). In the same vein, he lays out the intentionality of exclusionary practices:

We demonize and bestialize not because we do not know better, but because we refuse to know what is manifest and choose to know what serves our interests. That we nevertheless believe our distortions to be plain verities is no-counter argument; it only underlines that evil is capable generating an ideational environment in which it can thrive unrecognized. (Volf, 1996)

Selfishness blinds us to the true meaning of human relationships. Also, the fear of the other based upon difference, say, in skin colour or religion is by no means a hindrance to the exercise of empathy and respect. Difference should not be used as a weapon of dividing humanity. Rather, it is an asset. The archbishop of Canterbury Rowan Williams makes the contention that "The only humanity we have in common is bound up in difference, in the encounter of physical and linguistic others" (Qtd. in Denise, 2004). The bottom line is to harness the positivity of difference, and overlook whatever negativity it may carry for the benefit of mankind. Albino persons are ridden roughshod over basically because of the lamentable absence of what South African professor of Practical Theology, to wit Denise Ackermann, calls mutuality in relationship upon she elaborates as follows:

The concept of mutuality in human relationship is the touchstone against which the quality of our relationships is tested. Mutuality is concerned with feelings, needs, and interests of each other. Mutuality spells forbearance, generosity, kindness, forgiveness, considerateness-virtues often neglected.

(Denise, 2004)

Harking back to The Book of Memory, the lead character situates herself against a social background of borderline hatred for the albinos. Despite her fair share of stigmatization and discrimination, Memory cannot help but think beyond herself to bear witness to what another fellow albino, Lameck, goes through in terms of rejection. She describes Lameck as having "a squashed face and red, blotchy skin that broke over his arms and face" (Gappah, 2015). He runs a store where he sells tomatoes. Memory laments that despite "all the convenience that his store provided, he was not inundated with customers," (52). Memory is a textbook example of how a potentially bright future can be blighted by exclusion. Much as her "report every term spoke of a one hundred per cent pass rate in every subject," Memory is downright bruised by what she has been made to miss out on in terms of opportunities because of her illness: "had it not been for my condition. I would have been every teacher's dream" (Gappah, 2015). Interestingly, from the lead character's memories, the reader learns that both she and 
Lameck find in a crippling condition enough solace cum strength to negotiate the strictures of their 'othering'.

Just as Memory has had her fair share of albinism-related rejection, so does Lloyd for his sexual orientation. Memory's evocation in her memories of the recluse life of Lloyd bears witness to the lot of gay people in a society whose animus against homosexuality is dashed ingrained, and borders on hate. If anything, Lloyd felt compelled to use a woman, viz., Tracey Collins as a front to conceal his homosexual bent. Lloyd and Memory have a commonality-they know full well what it means to be 'othered.' As she contends: "Lloyd was as different to those around him as I was, that the fact of our difference bound us" (Gappah, 2015). The reader learns through the lead character's memories that, despite belonging to the privileged class thanks to his whiteness and wealth, Lloyd is hurting: "Not even Lloyd's whiteness could have saved him from the stigma of homosexuality because it is a stigma that cuts across race and tribe and religion and class and sex and political beliefs and all the artificial divisions this country has erected to keep people apart' (Gappah, 2015). His refusal to go public about his sexual orientation is steeped in the consciousness of a black-dominated country that treats gay people like dirt. Both Memory and her mentor, through no fault their own, are left out in the cold. The reason for their despicable "othering" rests on a deep-seated rejection of difference, and binary division that essentializes, so to speak, a set of normative behaviour, physical attributes and thinking. That is why Colette Guillaumin holds that the genuine significance of difference points to an established norm that excludes anything that does not fit in with a set paradigm. Guillaumin sees difference through the dyadic notions of 'distance' and 'centre.' She writes that:

The kennel of the meaning is the distance from the centre, the distance from a referent (still fero). In practice, one perhaps claims to mean: "' $\mathrm{X}$ and $\mathrm{Y}$ and (sic) different from each other'; but in reality one says ' $\mathrm{X}$ is different from Y'. Y is put in the position of the referent.

In short, difference is thought of (a) in a relationship, but (b) in a relationship of a particular type where there is a fixed point, a centre which orders everything around it, and which all things are measured, in a word, a REFERENT. This is in fact the hidden reality of difference. (Guillaumin, 1995)

Albinism and homosexuality may be poles apart. But they epitomize difference. Albinos and homosexuals are somewhat regarded as freaks of nature by those folks whose tunnel vision worldview blind to the universal values of dignity, freedom and justice. Colette Guillaumin's assertion that “All human beings are natural but some are more natural than others" (Guillaumin, 1995) speaks to how much difference-whether it be political, ethnic, racial or otherwise has split humanity. At one point in the narrative Memory admits stunningly: "I was as much a victim of my society as anyone else" (Gappah, 2015). In thinly veiled words, she takes aim at a hidebound society the hallmark of which is an agoni- 
zingly deep-rooted dislike of openness.

\section{Memory and Ethics}

For all the bad use it has been turned to, there is beauty in difference. Difference can, indeed, bring out the best in humanity notwithstanding the havoc that it wreaks due to people's warped view of it. Memory recalls that her albino-related suffering was alleviated with her fate-driven encounter with Lloyd. The latter is, indeed, a ray of sunshine for Memory. Through pep talk and good karma, Lloyd was able to heal Memory of much of the psychological and physical burden induced by her albinism, and make her whole. His exhortation to Memory not to allow the multifaceted strictures of albinism to get her down, says a mouthful: "It's your choice, Mnemosyne. You can spend your life feeling sorry for yourself, or you can simply choose not to. You can invite people's pity or you can refuse to be an object' (Gappah, 2015). By the same token, the contrast that Memory draws between her predicament and that of Lameck is an implicit shout-out to Lloyd: "Lameck in Mufakose had no Lloyd or Sister Mary Gabriel to...spend money at the dermatologist's and buy creams and lotions with sun filters, as Lloyd did for me after he bought me, ointments that healed and mended my skin" (Gappah, 2015). The sight of an albino person left to their own devices, and, to boot, being taunted derogatorily at every turn should elicit from any human being some degree of moral response. Lloyd's unflagging drive to help Memory weather the storm of the woes associated with her albinism justifies Avishai Margalit in confining memory to ethics (Margalit, 2004). Her life experience in Summer Madness in Umwinsidale is a standout feature of her whole past. Once her departure to Summer Madness becomes effective, she manages bit by bit to live down her woes thanks to the jaw-droppingly caring attitude of Lloyd. The evocation of Lloyd and the critical role he played in her future point to the uplifting value of caring. Caring, in Margalit's estimation, is a way of recognizing the humanity in the other: "Caring is merely a strong symptom that what we care about is important to us" (Margalit, 2004). Under the protection of Lloyd, Memory has taken a new lease of life. Following her being enrolled at Lloyd's expense at the Convent School in town, Memory feels as if made whole. Here's how she vents her sense of elation at being rescued from the jaws of nefarious scrutiny:

The Dominican Convent was like the world outside, only in miniature. Money got me what a top girls' school gives: slight arrogance, self-belief. ... I assumed a new identity.

It helped that money bought me a good skin, courtesy of a dermatologist. At school, I eventually became another girls in blue dress, and when I entered the secondary, another girl in a blue skirt and white blouse...

More than anything else, I felt an incredible sense of freedom not from want but from scrutiny. I had not yet found home, but I found a place where I could belong. (Gappah, 2015) 
This quotation may be long, yet it speaks volumes about an uplifting change in status for Memory. Also, this recall of her passage in a posh school is symbolic of emotional stability which was denied to her through derogatory look and language. That resilience bears testimony. That is, Memory has never allowed the social stigma of albinism to get her down. Rather, it has been wildly enabling in that it has given her the mental strength to face down dehumanization and debasement by successfully developing coping strategies. If anything, what constituted a bugbear for a good many prison inmates was not for her a heavy cross to bear:

The idea of being alone horrifies the others. They prefer to move in groups, to work in clusters, to always have a companion. It is different for me. Solitude is not the hardest thing about prison life for me. From the time that I was a child, I have been able to retreat into myself, and to find within myself the resources that have made it possible for me to bear my own company. (Gappah, 2015)

Memory's achievements despite the odds being stacked against her are nothing but a reproach to the misinformed classification of albinos as no-hopers owing to their epitome of difference. With the help of the "unstinting generosity" of Lloyd, Memory has shown that albinism is no hindrance to 'self-actualization'. She managed to overcome the psychological burden of her condition, and harness the leg up provided by Lloyd in order to be a success story.

When all is said and done, The Books of Memory is, as the title suggests, a paean to memory. With a felicitous turn of phrase and a jaw-dropping characterization, the Zimbabwean novelist Petinah Gappah has laid out the dynamics of memory. Indeed, the protagonist's arduous hassles in terms of trying flat out to accurately picture her past and recount it without fail point to the intricacy of memory, and its unstable as well as unfaithful nature. A spot-on reconstruction of the past is next to impossible owing to such strictures as the inescapable aspect of forgetting and the selectivity of memory. The dyadic edge of forgetting-active and passive according to the typology of Aleida Assmann-features prominently in the act of remembering, as is reflected in Memory's effort at recollection. The unstoppable flow of time and historical discontinuities mean that Memory is thwarted no end in her all-out drive to recall every facet of her past, not least the most painful, for the sake of the collective. In spite of the theory that memory is an articulation of what is no more, there is no denying that it impacts the present and helps shape the future. People always remember for a reason. Memory's relentless attempt to recall the memories made up of the wrongs and injustices wantonly meted out to her bespeaks a cathartic choice as well as an overpowering need to share them with the collective with an eye towards positive change.

${ }^{6}$ For more sidelights on the notion of 'self-actualization' I refer the reader to my paper "Binwell Sinyangwe's A Cowrie of Hope: A Tribute to Womanly Courage and Friendship" in European Journal of Literature, Language, and Linguistics Studies", Vol. 4, Issue 3, 2020. 


\section{A Potted Biography of the Author}

Petina Gappah (1971-) is a rising star in Zimbabwe's literary scene. Trained as a lawyer, Gappah dabbled in writing in her mid-teens, with her first story being published when she turned 14. The vibrancy of her writing coupled with the topical potency of her fictional themes earned her some literary awards, not the least which is the Guardian First Book Award. Since the inception of her career in writing, Petina Gappah has authored three books, to wit, Elegy for easterly (which is a collection of short story), and two back to back novels: The Book of Memory (2015) and Rotten Row (2016).

\section{Conflicts of Interest}

The author declares no conflicts of interest regarding the publication of this paper.

\section{References}

Alexander, J. C. (2004). Towards a Theory of Cultural Trauma. In J. C. Alexander, R. Eyerman, B. Giesen, N. J. Smelser, \& P. Sztompka (Eds.). Cultural Trauma and Collective Identity (pp. 1-30). University of California Press. https://doi.org/10.1525/california/9780520235946.003.0001

Assmann, A. (2008a). Canon and Archive. In A. Erll, \& A. Nünning (Eds.), Cultural Memory Studies: An International and Interdisciplinary Handbook (pp. 97-108). Walter de Gruyter.

Assmann, J. (2008b). Communicative and Cultural Memory. In A. Erll, \& A. Nünning (Eds.), Cultural Memory Studies: An International and Interdisciplinary Handbook (pp. 109-118). Walter de Gruyter.

Denise, A. M. (2004). Who is the Other?": Embodying Difference through Belonging. In W. Michael \&, J. A., Cynthia (Eds.), Loving God with Our Minds: The Pastor as Theologian (pp. 3-16). William B. Eerdmans Publishing Company.

Erll, A., \& Nünning, A. (Eds.) (2008). Cultural Memory Studies: An International and Interdisciplinary Handbook Walter de Gruyter. https://doi.org/10.1515/9783110207262

Fanon, F. (1986). Black Skin, White Masks. (Trans. by Charles Lam Markmann with Commentary by Ziauddin Sardar and Homi K. Bhabha). Pluto Press.

Fanon, F. (2004). The Wretched of the Earth. (Trans. Richard Wilcox with commentary by Jean-Paul Sartre and Homi Bhabha). Grove Press.

Fentress, J., \& Wickham, C. (1992). Social Memory. Blackwell Publishers.

Gappah, P. (2015). The Book of Memory. Faber and Faber Limited.

Guillaumin, C. (1995). Racism, Sexism, Power and Ideology. Routledge.

Halbwachs, M. (1992). On Collective Memory. (Trans., Lewis A. Coser from Les cadres sociaux de la mémoire, and from La Topographie légendaire des évangiles en terre sainte: Étude de mémoire collective.) The University of Chicago Press. https://doi.org/10.7208/chicago/9780226774497.001.0001

Hall, S., \& du Gay, P. (1990). Cultural Identity and Diaspora. In J. Rutherford (Ed.), Identity: Community, Culture, Difference (pp. 222-237). Lawrence \& Wishart.

Hall, S., \& du Gay, P. (1996). Questions of Cultural Identity. Sage Publications.

Klass, D., Silvermann, P. R., \& Nickmann, S. (Eds.) (1996). Continuing Bonds: New Un- 
derstandings of Grief. Routledge.

Kuhn, A. (2007). Photography and Cultural Memory. Visual Studies, 22, 283-292.

Lister, R. (2004). Poverty. Polity Press.

Margalit, A. (2004). The Ethics of Memory. Harvard University Press.

Martinson, P. V. (2004). What Then Shall We Do? In W. Michael, \& J. A., Cynthia (Eds.), Loving God with Our Minds: The Pastor as Theologians (pp. 3-16). William B. Eerdmans Publishing Company.

Moscovici, S. (2001). Social Representations: Explorations in Social psychology. G. Duveen., Ed., New York University Press.

Nair, R. B. (2002). Lying on the Postcolonial Couch: The Idea of Indifference. University of Minneapolis Press.

Nelson, K., \& Fivush, R. (2000). Socialization and Memory. In E. Tulving, \& F. I. M. Craik (Eds.), The Oxford Handbook of Memory (pp. 283-295). Oxford University Press.

Nora, P. (Ed.) (1996). Realms of Memory (English Language Edition). A. Goldhammer, Trans., Columbia University Press.

Oyserman, D., Elmore, K., \& Smith, G. (2012). Self, Self-Concept, and Identity. In M. R. Leary, \& J. P. Tangney (Eds.), A Handbook of Self and Identity (pp. 69-104). The Guilford Press.

Schwalbe, M., Godwin, S., Holden, D., Schrock, D., Thompson, S., \& Volkomir, M. (2000). Generic Processes in the Reproduction of Inequality: An Interactionist Analysis. Social Forces, 79, 419-452. https://doi.org/10.2307/2675505

Volf, M. (1996). Exclusion and Embrace: A Theological Exploration of Identity, Otherness, and Reconciliation. Abingdon Press.

wa Thiong'o, N. (1986). Decolonizing the Mind: The Politics of Language in African Literature. James Currey.

wa Thiong'o, N. (2009). Something New and Torn: An African Renaissance. Basic Ovistas Books.

White, H. (2000). Catastrophe, Communal Memory and Mythic Discourse: The Uses of Myth in the Reconstruction of Society. In B. Stråth (Ed.), Myth and Memory in the Construction of Community: Historical Patterns in Europe and Beyond (pp. 49-74). PIE-Lang. 